\title{
Measuring Competition in the Banking Sector of Pakistan: An Application of Boone Indicator
}

\author{
Mahmood ul Hasan Khan ${ }^{1}$ \\ Muhammad Nadim Hanif ${ }^{2}$
}

\begin{abstract}
The banking sector of Pakistan has witnessed a notable transformation in its structure and business activities following the implementation of financial sector reforms since the early 1990s. Specifically, the reforms helped transform a repressed financial sector into a market oriented and sound financial sector, predominantly owned and managed by the private sector. How these developments have impacted competition among the banks is still an open question. This study attempts to answer this question with the application of a recent approach to measure competition: Boone indicator of competitiveness. This measure postulates that inefficient firms (banks) in a competitive environment are punished harshly, and there is an output reallocation from inefficient to efficient firms/banks. We have estimated elasticity of market share to marginal costs for 24 banks in Pakistan, using a balanced panel of bank level (annual) data for the year 1996 to 2015. Marginal costs are obtained indirectly by first estimating a translog cost function using earning assets as an output, and cost of financial capital, physical capital and labor as inputs. The estimated Boone Indicator value of negative 0.31 is significant and suggests that inefficient banks have been losing their market share to efficient banks over the estimation period: a reflection of underlying competitive environment. Increasing value of Boone indicator (in absolute terms) over the period of study suggests that competition among the banks in Pakistan has increased over time.
\end{abstract}

\section{INTRODUCTION}

Operating environment for banks in Pakistan has witnessed substantial changes since the implementation of financial sector reforms in early 1990s. Specifically, privatization of state owned commercial banks was initiated, and private sector was encouraged to open new banks; directed credit schemes were gradually discontinued; cap on lending rate was abolished; branch licensing policy was liberalized; and use of information technology for the provision of financial services was facilitated. Moreover, State Bank of Pakistan (SBP) has been actively facilitating Islamic banking, branchless operations, and micro financing, to promote access to financial services. All these changes were designed to instill a healthy competition, and create a sound and an efficient banking system capable of supporting the growing economic activity. Understating of degree and evolution of bank competition is also important as it has strong implications for the way changes in monetary policy stance impact the ultimate underlying objectives. $^{1}$

Above developments have led to significant changes in the structure of the banking sector in Pakistan: the share of big 5 banks has declined from over 90 percent in early 1990s to 51.5 percent by end 2015; the ownership structure has changed from the public to the private sector

1- Additional Director, Monetary Policy Department, State Bank of Pakistan, Karachi.

2- Lead Economist, Research Department, State Bank of Pakistan, Karachi. muhammadnadeemhanif@yahoo.com

The views expressed in the paper are those of the authors not State Bank of Pakistan.

${ }^{I}$ During the last couple of decades SBP has itself come a long way to become an independent monetary policy decision maker.

JISR-MSSE

Volume 15

Number 2

July-Dec 2017 
as the later controls over 80 percent of banking assets; Islamic banks have emerged in banking arena, which control more than 10 percent of banking assets; and a number of foreign banks have switched their operations from a branch mode to full-fledged locally incorporated subsidiaries to expand their businesses. ${ }^{2}$ All this suggests that the level of competition must have been changing over time.

Literature on measuring competition has also been evolving along with developments in the banking sector around the globe as well as in Pakistan. It started exploring banking sector competition on the lines of industrial organization using 'structure-conduct-performance' and 'efficient structure' paradigms as we discussed in Khan and Hanif (2017a). The deficiencies in the structural measures of competition encouraged the use of formal tests, like Panzar-Rose (1987) H- statistic (as we used in Khan and Hanif, 2017b) to assess the underlying competitive environment of the banking sector. While PR-H statistic is useful to know the degree of competition among the banks in a country, it does not give any clue on how competition is evolving in the banking sector.

This issue was addressed by J. Boone in a series of studies conducted during 2000 and 2008 to develop a new measure of competition: 'performance-conduct-structure'. This was later named as Boone Indicator by the researchers who used this approach in their empirical studies on competition. This measure is based upon a simple intuition that an increase in competition reallocates output from less efficient to more efficient firms (banks). Griffith et al. (2005) validated the idea of Boone by using simulated dataset. It was found that Boone Indicator outperforms traditional measures of competition including concentration ratio.

Given the substantial changes as a result of financial sector reforms in Pakistan, there is need to study how competition has evolved over time in the country during the last two decades. In Khan and Hanif (2017a and 2017b), we have reviewed studies on competition in the banking sector of Pakistan including Arby (2003), Khan (2009), and Bhatti and Hussain (2010). None of these studies had used this new indicator of measuring competition in the banking sector of Pakistan. Mirza et al. (2016), however, assessed the competition in the banking industry of Pakistan over the period of 2004-2012 by using the Boone Indictor (along with other indicators), but the authors did not analyze the evolution of competitive environment in banking industry over the period of analysis. Objective of our study is to fill this research gap and measure (estimate) the level of competition in the banking sector of Pakistan, with a view to explore how competition has evolved over time in the country during the last two decades.

In these settings, this paper presents temporal analysis of competition in the banking sector of Pakistan by using a recent approach developed by Boone (2000, and 2008). This is the first ever research study applying this novel (Boone indicator) approach to provide a time series estimate of competition in the banking industry of Pakistan, based on a large panel data of 24 commercial banks from the year 1996 to 2015, which uses estimated marginal cost (rather than proxy it with average cost). This paper is organized into six sections. Introduction in this section is followed by a brief review of literature in section 2 . Section 3 presents theoretical underpinnings of the recent approach to measuring competition used in this study. Data description and selection of variables is the subject of Section 4 , which is followed by the estimation and interpretation of empirical results in section 5. The final section concludes the paper.

${ }^{2}$ These issues are discussed at length in Khan and Hanif (2017a). 


\section{LITERATURE REVIEW}

Lack of any direct measure of competition rendered the policy makers and researchers around the globe to explore different indicators which can exhibit the underlying level of competition. Traditional theory of industrial organization focused on the market structure to analyze competition, ${ }^{3}$ which led to the development of various indicators related to the market structure including Concentration Ratio, Herfindahl-Hirschman Index (HHI), Hall-Tideman Index (HTI) etc. All these measures assign weights according to the size of firms (banks) in the sample to understand the market structure. ${ }^{4}$

A credible challenge to structure-conduct-performance (SCP) paradigm came from an efficiency-based competing explanation for higher concentration. The basic intuition is that the efficient banks/firms grow at a higher pace as compared to their peers. As a result, market share of the efficient banks/firms increases over time, which ultimately contributes towards market concentration. This is popularly known as an efficient structure (ES) paradigm. ${ }^{5}$

Given the strong theoretical underpinnings of both SCP and ES paradigms, the subsequent theoretical research on competition primarily focused on the conduct or behavior of firms/banks to understand competition in the market. The most notable development was the introduction of $\mathrm{H}$-statistic to formally test the underlying market structure (Rosse and Panzar (1977), Panzar and Rosse (1987)). This test essentially measures the pass through of changes in input prices to the revenue under the standard assumption of market equilibrium.

While the PR-H model is a useful measure to classify the underlying market structure into three broad categories (perfect, monopoly and monopolistic competition), it is difficult to analyze the impact of policy interventions on the level of competition. Moreover, this model can only be applied to "investigate the competitive nature of the all banking activities" (Leuvensteijn et al. 2011). These issues are largely addressed in a new measure of competition, popularly known as Boone indicator or relative profit differences (RPD) or performance conduct structure (PCS). ${ }^{6}$ In a series of papers, Boone (2000, 2004 and 2008) and Griffith et al. (2005), a new measure of competition was developed based on a widely held intuition that an increase in "competition reallocates output from less efficient to more efficient firms".

Empirical evidence in favor of this recent measure is provided in Griffith et al. (2005), which used simulated data to show that the new measure based on relative profits outperforms the traditional measures of competition (the HHI, concentration ratios, market shares, and price-cost-margin), especially in markets where the marginal costs and products are symmetrically differentiable.

Schaeck and Cihak (2010) explained the philosophy behind Boone indicator as a measure of the degree of competition and estimated the Boone Indicator for US and a large number of European countries in order to assess 'how competition enhances banking soundness'. Similarly, Mirzaei and Moore (2014) studied the determinants of banking competition across different income groups by using Boone Indicator (along with Lerner Index) as measure of competition for 146 countries over the period of 1999-2011. More recently, Clerides et al. (2015) measured the degree of banking competition in terms of Boone Indicator (along with

\footnotetext{
${ }^{3}$ The SCP paradigm assumes one-way causation from the market structure to performance.

${ }^{4}$ For details, see Hall-Tideman (1967); Adelman (1969); Davies (1979); Kwoka (1985); and Rhoades (1995).

${ }^{5}$ For details, see Demsetz (1973) and Peltzman (1977)

${ }^{6}$ Boone himself termed this new measure as performance-conduct-structure while other researchers named is as a Boone Indicator. 
Lerner Index and Adjusted Lerner Index) for 148 countries using bank-level data for 1997 to 2010. Studies like Schaeck and Cihak (2010), however, used average cost to proxy marginal cost in estimation process. World Bank (2017) attempted to overcome this shortcoming and used marginal cost to estimate the Boone indicator pertaining to banking market for large number of countries using Bankscope dataset, including for Pakistan, over 1999-2014 period only. The estimates of Boone indicator for individual countries in cross countries studies like Mirzaei and Moore (2014) are less likely to be subject to rigorous analysis because the same specification is utilized for all the countries and any single country is not focused. The country-specific detailed information, especially for developing countries like Pakistan, is rarely used in cross-country studies due to lower weight and broad focus of the studies. Even in case of World Bank (2017), the Bankscope dataset is largely confined to big banks. Furthermore, Bankscope information is less likely to be as detailed as is generally available with the country's central banks. It is not clear how many banks have been used in construction of Boone indicator for banking market of Pakistan. We can see significant volatility in the Work Bank (2017) estimated Boone indicator for Pakistan, particularly in recent years.?

As far as country study on Pakistan is concerned, Mirza et al. (2016) is the first one which attempted to assess competition among banks in Pakistan (for the period of 2004-2012) using Boone Indicator (along with other indicators of measuring competition). In this study again, the authors used average cost to proxy the marginal cost. This approximation implicitly put a strong assumption on the analysis as the marginal cost would be equal to average cost only at the equilibrium point. A precise measure of marginal cost in line with economic theory can be derived from the cost function (as we discuss in the methodology section). We rely on a well-known translog cost function (TCF) and use a convenient approximation to estimate the marginal cost.

In the backdrop of above discussions, we study competition in banking sector of Pakistan by applying this recent approach (Boone indicator) while using (log of) market share as dependent variable in estimation of Boone Indicator. We use a measure of marginal cost instead of average cost (which has been used in Boone (2000, 2004 and 2008), Griffith et al. (2005), Schaeck and Cihak (2010) and Mirza et al. (2016). We also improved upon the way variables used in this study are measured as discussed in following section in details.

\section{METHODOLOGY}

Relying on theoretical underpinning of the efficiency hypothesis, Boone (2000) introduced the concept of relative profit differences by arguing that inefficient firms are punished more heavily in a highly competitive industry. In other words, there is an output reallocation from inefficient to efficient firms in a competitive market. ${ }^{8}$ The reallocation effect must be analyzed in monetary terms as firms (banks) may be producing more than one products, which could be close substitutes instead of perfect substitutes (Boon, 2004 and 2008). In practice, both revenues and costs could be used to express this reallocation effect. However, the costs are preferred over the revenues because prices will take into account the impact of both intensifying competition and firm's output.

\footnotetext{
${ }^{7}$ The magnitude of Boone indicator was negative 0.5 in the year 2012, which turned into positive 0.32 in the years 2014, for example

${ }^{8}$ It is interesting to note that this reallocation effect is also a necessary condition for interpreting a decrease in price-cost-margin as an increase in competition.
} 
Following Griffith et al. (2005) and Leuvensteijn et al. (2013), competition can be analyzed by using the following functional form.

$$
\ln \left(M S_{i}\right)=\beta_{0}+\beta_{1} \ln \left(M C_{i}\right)+\varepsilon_{i}
$$

Where $\mathrm{MS}_{\mathrm{i}}$ is the market share and $\mathrm{MC}_{\mathrm{i}}$ is the marginal cost of bank $i$. The parameter $\beta_{1}$, named as Boone indictor in the literature, is expected to be negative as market share of banks with relatively low marginal costs (more efficiency) should increase to satisfy the idea of relative profit differences. Higher value of $\beta_{1}$ in absolute terms reflects stronger competition as the inefficient banks (having higher marginal costs) would be punished more harshly. Moreover, the above specification can also be used to analyze competition over time by estimating $\beta_{1}$ for each year. The choice of functional form is open to research. However, the $\log$ liner specification would help reduce problem of heteroskedasticity as variation in marginal costs across banks should be expected.

A key issue in the estimation of above functional form is the calculation of marginal cost $\left(\mathrm{MC}_{\mathrm{i}}\right)$, which cannot be obtained directly from the balance sheet and income accounts of banks/firms. Griffith et al. (2005) suggested to use average costs to revenue ratio as a proxy for marginal costs of firms. Following Griffith et al. (2005), Schaeck and Cihak (2010) and Mirza et al. (2016) proxied the marginal cost by average cost. However, a more precise measure of marginal cost in line with economic theory can be derived from the cost function. Following Mirzaei and Moore (2014) this study relies on well-known translog cost function, which provides a convenient second order approximation of an arbitrary cost function. If we denote factor input prices by $P_{j}$, respective input quantities by $X_{j}$, and the level of output by $\mathrm{Q}$, total cost (TC) would equate to $\sum \mathrm{P}_{\mathrm{j}} * \mathrm{X}_{\mathrm{j}}$. TCF for one output (earning assets), and three inputs (funds, labor, and physical capital) can be expressed as follows.

$$
\begin{aligned}
& \ln \left(\mathrm{TC}_{\mathrm{it}}\right)=\alpha_{0}+\gamma_{\mathrm{Q}} \ln \left(\mathrm{Q}_{\mathrm{it}}\right)+\frac{1}{2} \gamma_{\mathrm{QQ}}\left(\ln \mathrm{Q}_{\mathrm{it}}\right)^{2}+\sum_{\mathrm{j}} \alpha_{\mathrm{j}} \ln \left(\mathrm{P}_{\mathrm{j}, \mathrm{it}}\right) \\
& +\sum_{\mathrm{j}} \gamma_{\mathrm{jQ}} \ln \left(\mathrm{P}_{\mathrm{j}, \mathrm{it}}\right) \ln \left(\mathrm{Q}_{\mathrm{it}}\right)+\frac{1}{2} \sum_{\mathrm{j}} \sum_{\mathrm{k}} \gamma_{j \mathrm{k}} \ln \left(\mathrm{P}_{\mathrm{j}, \mathrm{it}}\right) \ln \left(\mathrm{P}_{\mathrm{k}, \mathrm{it}}\right)+\epsilon_{\mathrm{it}}
\end{aligned}
$$

For all $\mathrm{j}, \mathrm{k}=\mathrm{F}, \mathrm{K}, \mathrm{L}$, symmetry condition on cross price impact implies that $\gamma_{\mathbf{j k}}=\gamma_{\mathbf{k j}}$. In above specification, $\mathrm{TC}_{\mathrm{it}}$ are the total cost of bank $\mathrm{i}$ in time period $\mathrm{t}, \mathrm{Q}_{\mathrm{it}}$ is the output or asset portfolio of bank $i$ in time period $t$, and $P_{i, i t}$ is the input price of factor $j$ of bank $i$ in time period $t$.

To ensure theoretical consistency of the standard cost function, TCF must be linearly homogeneous in factor input prices, and fulfill the condition of cost-exhaustion. Linear homogeneity ensures that total costs will increase in proportion to the increase in factor input price if we keep the level of output unchanged. Symbolically, the following restrictions are imposed on the parameters of TCF.

$$
\sum_{\mathrm{j}} \alpha_{\mathrm{j}}=1, \quad \sum_{\mathrm{j}} \gamma_{\mathrm{jQ}}=0, \text { and } \quad \sum_{\mathrm{j}} \gamma_{\mathrm{jk}}=\sum_{\mathrm{k}} \gamma_{\mathrm{kj}}=\sum_{\mathrm{j}} \sum_{\mathrm{k}} \gamma_{\mathrm{jk}}=0
$$


Marginal cost from TCF can easily by obtained by differentiating it with respect to output. This differentiation yields the following expression.

$$
\frac{\partial \ln \left(\mathrm{TC}_{\mathrm{it}}\right)}{\partial \ln \left(\mathrm{Q}_{\mathrm{it}}\right)}=\gamma_{\mathrm{Q}}+\gamma_{\mathrm{QQ}} \ln \left(\mathrm{Q}_{\mathrm{it}}\right)+\sum_{\mathrm{j}} \gamma_{\mathrm{jQ}} \ln \left(\mathrm{P}_{\mathrm{jit}}\right)
$$

\section{As we know that:}

$$
\frac{\partial \ln \left(\mathrm{TC}_{\mathrm{it}}\right)}{\partial \ln \left(\mathrm{Q}_{\mathrm{it}}\right)}=\frac{\partial \mathrm{TC}_{\mathrm{it}}}{\partial \mathrm{Q}_{\mathrm{it}}} * \frac{\mathrm{Q}_{\mathrm{it}}}{\mathrm{TC}_{\mathrm{it}}}=\mathrm{MC}_{\mathrm{it}} * \frac{\mathrm{Q}_{\mathrm{it}}}{\mathrm{TC}_{\mathrm{it}}}
$$

It implies that $\mathrm{MC}_{\mathrm{it}}$ would equate the following expression.

$$
\mathrm{MC}_{\mathrm{it}}=\left\{\gamma_{\mathrm{Q}}+\gamma_{\mathrm{QQ}} \ln \left(\mathrm{Q}_{\mathrm{it}}\right)+\sum_{\mathrm{j}} \gamma_{\mathrm{jQ}} \ln \left(\mathrm{P}_{\mathrm{jit}}\right)\right\} * \frac{\mathrm{TC}_{\mathrm{it}}}{\mathrm{Q}_{\mathrm{it}}}
$$

\section{In this study, $\mathrm{MC}_{\mathrm{it}}$ is obtained by using above expression for onward}

We estimate the parameters of TCF using maximum likelihood estimator (MLE). After getting marginal cost (as discussed), we estimate Boone Indicator from equation (1) using Generalized Method of Moments (GMM) while taking care of heteroskedasticity by considering cross-sectional weights. Following the practice in the literature we use lagged values of explanatory variable as instruments.

\section{DATA AND CONSTRUCTION OF VARIABLES}

Primary data source for entity-level information is the annual audited accounts of banks. In this study, we used balanced panel data of banks operating in Pakistan from the year 1996 to 2015. Unreliable and irrelevant observations were excluded to compile a consistent data set: specifically, banks with negative equity \& admin expenses, over 20 percent cost of funding, and unreasonably high labor cost, were excluded from the sample. Most of the banks, which could not meet the criterion, were (i) foreign banks operating in branch mode, (ii) small private banks, and (iii) the specialized banks.9 As a result of this filtration, we were left with 24 banks, which hold (on average) 90.8 percent of banks' total assets with a range of 89.6 to 92.7 percent during the period of analysis.

While data collection from audited accounts is straightforward, defining input and output prices and quantities is a tricky exercise, since in case of banking firm none of these variables are directly observable from the accounts. Financial product-wise information is not available, and so is the case for input costs. This situation is further complicated as banks perform many auxiliary services, which are extremely difficult to price. For example, it is not easy to assign a monetary value to banks' risk management, allocation of resources, funds transfers, etc., since banks utilize the same resources to perform all type of financial services. One of possible solutions to these issues is to rely on some sort of aggregate and indirect measures. In this study, the output and input prices, and other variables used in estimation are defined as follows.

\footnotetext{
${ }^{9}$ Three specialized banks owned by the public sector were not included, as these banks primarily rely on equity or borrowing (instead of deposits) for their lending activities. Moreover, the government policies heavily influence their business activities instead of the developments taking place in the banking system.
} 


\section{Total cost and variable cost}

Total expenses are readily available from the income statement of banks. However, these take into account taxes, provision against bad debts or the debts directly written off by banks, and other expenses, which are hard to classify. Boone (2008) suggested that "any costs, like materials and energy, that are viewed as variable costs (i.e. varying with small changes in production) should be included" in the variable costs. We have defined variable cost as the sum of interest paid on bank deposits and borrowing, and administration expenses (which includes the salaries and other operating expenses).

\section{Banks' output $(Q)$}

Defining banks' output is a difficult task as there is no agreement among the policy makers as well as researchers that what should be considered as banks' output. In particular, what should be the treatment of banks' deposits: a product of banking system or an input for banks' lending. In practice, treatment of deposits as an output or input depends on the objective of the study. In this study, deposits and borrowing are treated as inputs because banks have to pay interest to the depositors, which is a cost for banks (Leuvensteijn et al. (2013). The next question arises: which assets should be included as an output? One option is to include total assets (Andries and Capraru, 2012). In this study, we considered a single output comprising banks' earning assets. Specifically, earning asset portfolio includes banks' loans/advances, investments, lending to other financial institutions, and funds placed with other banks.

\section{Cost of labor (ACL)}

Average labor cost is obtained by taking a ratio of expense on salaries and allowances to the number of bank employees. This information was available from the year 2000 to 2015 . For earlier four years (1996-1999), we followed Khan (2009) and bifurcated admin expenses into salaries and other operating costs by using average share for the year 2000 to 2003, while the data on number of employees was readily available from the year 1996 onwards. In literature, various other proxies are also used like admin expenses to total assets (Bikker et al.2006), and personal expense to total assets (Gajurel and Pradhan, 2012 and Andries and Capraru, 2012). This second best approximation is largely used due to absence of data on number of employees.

\section{Cost of physical capital (ACK)}

Unlike cost of labor, it is difficult to find a proxy for cost of physical capital as both the cost and the amount of physical capital used during a specified period, are not directly observable. We follow the literature and proxy cost of physical capital by the ratio of other admin expenses (admin expenses net of salaries and employees related benefits) to operating fixed assets. ${ }^{11}$

\footnotetext{
${ }^{10}$ It may be noted that TCF is flexible enough to account for multiple outputs. We used single output as information on interest earned on banks' loans and investments, is not separately available over the sample period. Moreover, the objective is to estimate the marginal cost of overall banking activities, not to study the marginal cost of extending loans and making investments in government securities.

${ }^{11}$ Claessens and Laeven (2004), Bikker et al. (2006a), Gajurel and Pradhan (2012), and Andries and Capraru (2012) used the same definition.

JISR-MSSE

Volume 15

Number 2

July-Dec 2017 


\section{Cost of (funding) financial capital (ACF) vv}

Compared with the cost of physical capital, the calculation of cost of financial capital is relatively straightforward. Information on total interest paid on deposits, borrowing or other short terms funds, is directly available from banks' income statements. Similarly, data on banks interest rate sensitive liabilities (deposits, borrowings, and subordinated-debt, etc.) can be obtained from banks' balance sheets. Therefore, average cost of financial capital is calculated by taking a ratio of total interest expense to average of interest bearing liabilities at the beginning and at the end of the year.

\section{Market share (MS)}

While the calculation of banks' market share hardly deserves mention due to its simplicity, a key issue was whether to use the total assets of 24 banks included in our sample or the overall assets of the banking system. We used overall assets as it ensures that the market share of bank $\mathrm{i}$ is influenced by the changes in the assets of all other banks operating in Pakistan. It is important to include the impact of reallocation of financial services from inefficient to relatively efficient banks.

While the calculation of marginal cost for each bank is a part of the empirical results, definitions and descriptive statistics of all other variables used in estimation are provided in Table 1 and Table 2, respectively. Descriptive statistics indicate notable variation in the data. For example, the smallest bank in the data set has the market share of only 0.02 , against 23.84 percent for the largest bank. Average cost of funding, which plays a key role in determining the banks' lending rate varies from less than one percent to 14.6 percent. Regardless of the reasons, the low cost of funding compared to the peers creates an opportunity to enhance the market share. Similar variation is visible from other indicators.

Table 1: Definitions/ Data Description

\begin{tabular}{|c|c|c|}
\hline & Units & Definition \\
\hline \multicolumn{3}{|c|}{ Dependent variables } \\
\hline $\mathrm{TC}$ & Million Rupees & Total expenses: interest paid, admin expense, taxes, expense on provisions \& other expense \\
\hline $\mathrm{VC}$ & Million Rupees & Variable costs: interest paid and admin expenses \\
\hline \multicolumn{3}{|c|}{ Explanatory variables } \\
\hline \multicolumn{3}{|c|}{ Input variables } \\
\hline$P_{L}$ & Million Rupees & Cost of labor: ratio of salaries, allowances and other benefits to number of employees \\
\hline$P_{F}$ & Percent & Cost of funding: Interest expense to average interest bearing liabilities \\
\hline$P_{K}$ & Ratio & $\begin{array}{l}\text { Cost of capital: ratio of other administrative cost net of personal expense (salaries, allowances } \\
\text { etc. to employees) to average operating fixed asset. }\end{array}$ \\
\hline \multicolumn{3}{|c|}{$\overline{\text { Output }}$} \\
\hline$Q$ & Million Rupees & $\begin{array}{l}\text { Earning assets: advances, investments, balance with other banks, and lending to financial } \\
\text { institutions. }\end{array}$ \\
\hline \multicolumn{3}{|c|}{ Other variables } \\
\hline MS & Percent & Market Share- share of bank's assets in total assets of the banking system \\
\hline
\end{tabular}


Table 2: Descriptive Statistics

\begin{tabular}{llrrrr}
\hline Variable & Unit & Minimum & Maximum & Mean & Std. Dev. \\
\hline$P_{K}$ & Ratio & 0.03 & 21.07 & 1.32 & 1.85 \\
$P_{F}$ & percent & 0.62 & 14.62 & 6.23 & 2.69 \\
MS & Percent & 0.02 & 23.84 & 3.78 & 4.94 \\
$P_{L}$ & Mln. Rs & 0.09 & 6.72 & 0.62 & 0.62 \\
Q & Mln. Rs & 134.9 & $1,888,706$ & $161,832.4$ & $253,648.9$ \\
VC & Mln. Rs & 19.9 & $113,410.6$ & $12,860.8$ & $18,684.4$ \\
TC & Mln. Rs & 2.6 & $120,447.5$ & $14,322.3$ & $20,559.8$ \\
\hline
\end{tabular}

Source: authors' calculation

\section{ESTIMATION AND RESULTS}

Parameters of TCF as specified in the methodology section are estimated by using the maximum likelihood estimator upon bank-level data from the year 1997 to 2015. The initial step in this procedure is to estimate parameters by using OLS and create a covariance matrix from the residuals. This covariance matrix is used to obtain new estimates of the parameters, and this process is iterated till the convergence is achieved. We used convergence level of 0.0001 , and it took 26 iterations to achieve this level of convergence. Estimated parameters along with standard errors are reported in Table 3.

Table 3: Results of Translog Cost Function

\begin{tabular}{|c|c|c|c|c|c|}
\hline Parameter & Estimate & Standard Errors & Parameter & Estimate & Standard Errors \\
\hline$\alpha_{0}$ & -0.6377 & 0.5469 & $\gamma_{Q}$ & $0.4923^{\circ}$ & 0.1001 \\
\hline$\alpha_{r}$ & $0.4647^{*}$ & 0.0769 & $\gamma_{Q Q}$ & $0.0456^{*}$ & 0.0091 \\
\hline$r_{m}$ & $0.1527^{*}$ & 0.0189 & $\alpha_{K}$ & 0.0725 & 0.1243 \\
\hline$\gamma_{n}$ & $-0.0634^{*}$ & 0.0170 & $\gamma_{K \kappa}$ & $0.0705^{*}$ & 0.0256 \\
\hline$\gamma_{F x}$ & $-0.0893^{*}$ & 0.0141 & $\gamma_{K Q}$ & 0.0171 & 0.0114 \\
\hline$\gamma_{F Q}$ & 0.0019 & 0.0073 & & & \\
\hline$\alpha_{L}$ & $0.4628^{*}$ & 0.1249 & & & \\
\hline$\gamma_{u t}$ & $0.0447^{\wedge}$ & 0.0249 & Na. of iterations & 26 & \\
\hline$\gamma_{L X}$ & 0.0188 & 0.0239 & No. of observations & 456 & \\
\hline$\gamma_{L Q}$ & $-0.0190^{\circ}$ & 0.0108 & RSS & 14.8542 & \\
\hline
\end{tabular}

Being a flexible functional form, TCF does not impose restrictions of well behaved cost function, and the restrictions required to satisfy duality between the production and cost functions. It implies one must analyze the validity of underlying restrictions before interpreting the results. As noted in the earlier section, the restriction of cross-price symmetry is already imposed for the parameter estimates as $\gamma_{\mathrm{jk}}=\gamma_{\mathrm{kj}}$. The monotonicity properties of the cost function are analyzed by evaluating estimated shares of factor inputs at each observation. ${ }^{13}$ With the exception of few observations, positive values of estimated shares of factor inputs at each observation indicate that estimated cost function is monotonic in prices. ${ }^{14}$

${ }^{12}$ Data for the year 1996 was utilized to take average of values by using information at the beginning and end of the year.

${ }^{13}$ Monotonicity in prices implies that total cost must increase due to an increase in process of factor inputs, while holding the output constant. Similarly, monotonicity in output implies that total cost must increase due to an increase in output, while keeping the prices of factor input unchanged.

${ }^{14}$ Average value (along with range of estimated factor shares) are $0.81(0.28$ to 1.16$), 0.11$ (-0.15 to 0.35$)$, and 0.08 ( -0.01 to 0.37$)$ for cost of funding, labor and capital, respectively.

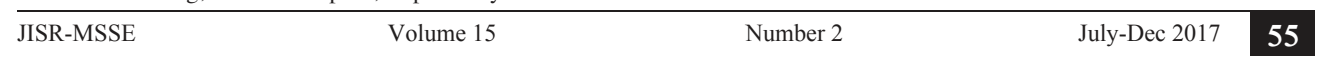


Similarly, monotonicity in output is analyzed by evaluating partial derivative of cost function with respect to output. None of the observation was negative, suggesting monotonicity properties are satisfied over the estimation period. ${ }^{15}$

Tuming to the interpretation of estimated cost function, the individual parameters provide interesting insights related to input elasticities and changes in input shares due to an increase in output ( $\gamma_{\mathrm{jQ}}$ coefficients). Although prime objective of estimating cost function in this study is to calculate marginal cost for further estimation of Boone indicator, it would be instructive to analyze scale economies, which are defined as follows.

$\mathrm{SE}=1-\frac{\partial \ln \left(\mathrm{TC}_{\mathrm{it}}\right)}{\partial \ln \left(\mathrm{Q}_{\mathrm{it}}\right)}$

The evaluation of above expression indicates that average value of scale economies over the estimation period is 0.003 (or 0.3 percent). This small value is an indication of weak evidence in favor of scale efficiency.

The marginal cost $\left(\mathrm{MC}_{\mathrm{it}}\right)$ series is generated by using an expression obtained by differentiating TCF with respect to output. The estimated marginal cost ranges from 0.02 to 0.31 , with an average of 0.10 over the estimation period. This variable is subsequently used to estimate Boone Indicator as specified in Equation 1. This simple regression is estimated by using Generalized Method of Moments (GMM) with options of cross-section weights to minimize the problem heteroskedasticity. Lagged values of explanatory variable $\left(\ln \left(\mathrm{MC}_{\mathrm{it}}\right)\right)$ are used as instruments to resolve the problem of simultaneity.

The results indicate that the coefficient (Boone indicator- $\mathrm{B}$ ) has expected negative sign with value 0.31 , and is statistically different from zero. ${ }^{16}$ Specifically, 100 bps higher marginal cost of a bank is associated with 31 bps loss of market share. It implies that Pakistan has a competitive banking sector as banks with higher marginal cost (inefficient banks) are losing their market share to banks with lower marginal cost (efficient banks). This result is in line with the findings of Claessens and Laeven, (2004), Bikker et al. (2006) and Khan (2009) based on different estimation techniques. All these studies used PR-H Statistics and concluded that banking sector of Pakistan reflects the behavior of monopolistically competitive market structure.

\footnotetext{
${ }^{15}$ Average value along with range is 0.997 (0.77 to 1.15$)$.

${ }^{16}$ This result (related to the competition in banking market of Pakistan) is robust to considering industry specific bank specific indicators of banks in the country in the estimation. The estimated value of value of Boone indicators is negative 0.22 if the basic equation is augmented to take into account the impact of market concentration (an industry specific indicators proxy by the concentration ratio of top 5 banks) and banks capitalization (equity to asset ratio of banks to proxy banks' soundness). This estimate is also statistically different from zero. Both the results suggest the same thing: a bank with higher marginal cost loses its market share to other banks (in Pakistan) with lower marginal cost.
}

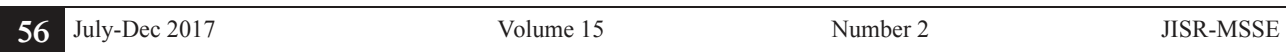




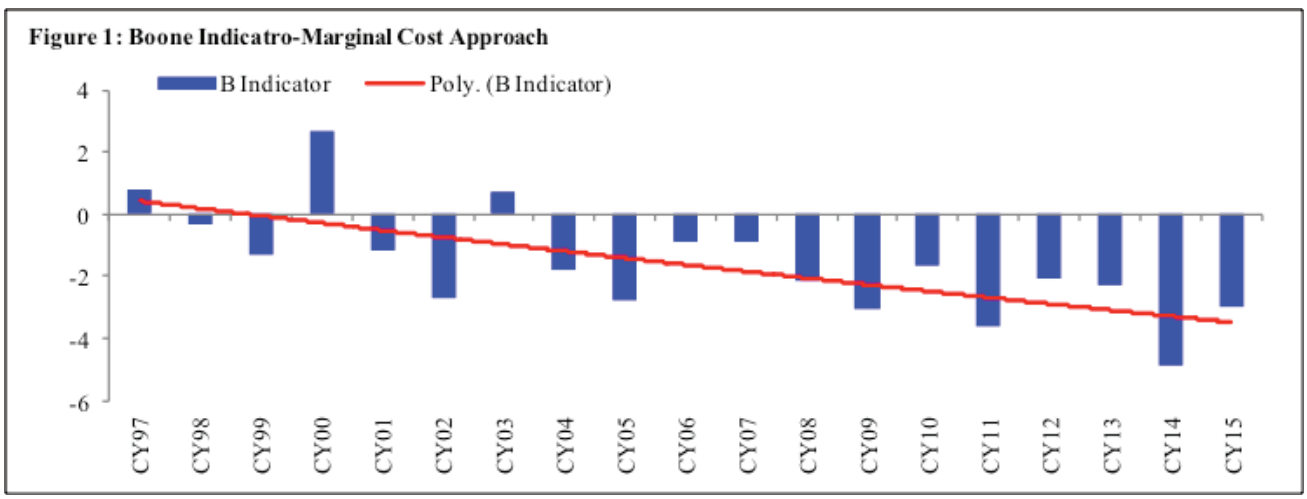

In the next step, we estimate BI for each year by using market shares and marginal costs of 24 banks in our sample. Figure 1 shows that value of BI varies from positive 2.7 to negative 4.9, and it is negative for 16 of 19 years. ${ }^{17}$ Moreover, BI has relatively larger values in absolute terms in the recent years, reflecting stronger competition. Similarly, relatively low values from $\mathrm{CY} 06$ to $\mathrm{CY} 07$ reflect some reduction in the level of competition as compared to the past years. This corroborates well with the developments taken place in banking sector during the same period. For example, growth in banks' assets has substantially reduced and overall economic activity has also slacked. ${ }^{18}$ In such an environment, some reduction in the level of competition was expected, since the banks were in the phase of re-aligning their business strategies. The banking sector has successfully recovered from that episode, and is reflecting a stronger competition for the recent period.

\section{Robustness Check}

To check the robustness of above results, we re-estimate Boone Indicator by using a different methodology proposed by Griffith et al. (2005). This methodology focuses on relative profits, which are measured as "the difference (or change) in profits over the difference (or change) in average variable costs". In regression form, this could be specified as follows:

$\ln \left(\pi_{\text {it }}\right)=\alpha+\beta *\left(\right.$ AVC $\left._{\text {it }}\right)+\varepsilon_{\text {it }}$

Where $\ln \left(\pi_{i t}\right)$ is a profit of bank $i$ in time period $t, A V C_{i t}$ is the average variable costs, and the parameter $\beta$ is interpreted as Boone Indicator (BI). For the estimation of above regression, profit is defined as the difference between total revenue and the variable cost (sum of interest payment and admin expenses). The average variable cost is defined as a ratio of variable cost to output (earning assets). The GMM estimate of parameter $\beta$ has expected negative sign and its value is 1.3 , reflecting

\footnotetext{
${ }^{17}$ The World Bank estimates of Boone indicator for Pakistan ranges from negative 0.5 (year 2014) to positive 0.32 (the year 2012). Moreover, the value of Boone indicator was negative for 14 of 17 years.

${ }^{18}$ Pakistan faced a balance of payment crisis in the year 2008, and the country was forced to utilize the IMF support to stabilize the economy.
} 
the competitive behavior of banks. It implies that inefficient banks are penalized harshly in terms of loss in profits, which confirms the finding based on the marginal cost and market share approach.

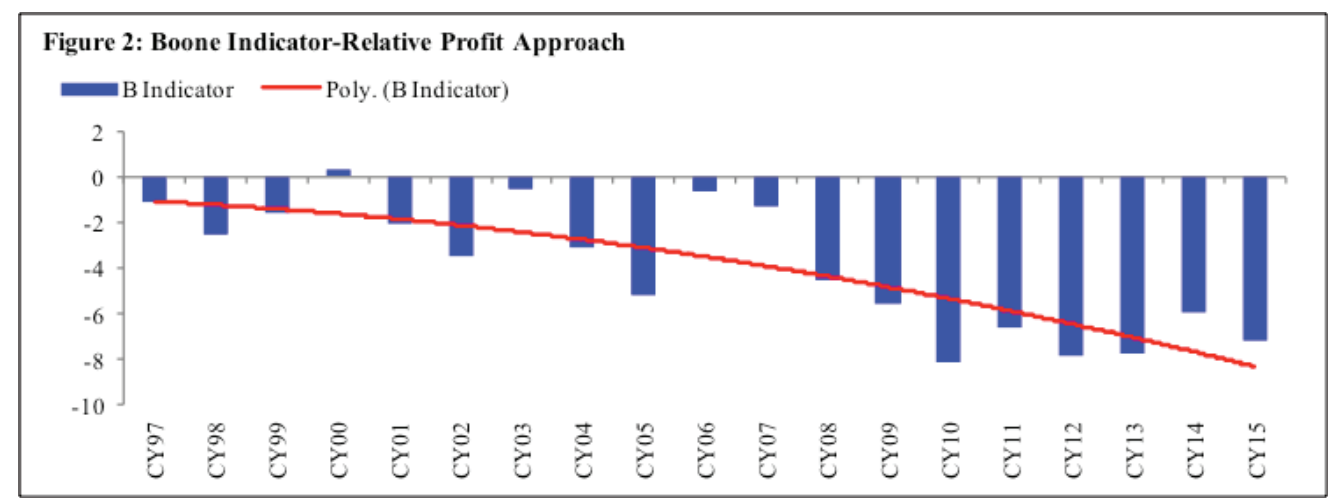

Yearly estimates of BI vary from negative 8.1 to positive 0.3 . Figure 2 depicts that BI has negative value for 18 of 19 years in our sample. Furthermore, BI values almost follow the same pattern as we have seen in case of marginal cost. This lends credence to our earlier results that banking sector of Pakistan exhibits a competitive behavior over the estimation period, and the level of competition has gradually increased in the recent years.

\section{SUMMARY AND CONCLUSION}

This paper investigates competition in the banking sector of Pakistan by using a recent approach, popularly known as Boone Indicator. This approach is based on the intuition that inefficient firms are punished harshly in competitive markets, which leads to reallocation of output from inefficient to efficient firms. Theoretically, this intuition suggests a negative relationship between the market share and marginal costs of firms/entities or between the profits and average variable costs. This study explored these links in the context of competition by using (balanced) panel data of 24 commercial banks operating in Pakistan from the year 1996 to 2015 .

In the first step, we estimated a translog cost function with three inputs. The parameter estimates were used to calculate marginal cost (consistent with economic theory), which is not directly observable from the income statements of the banks. In the second step, we estimated a simple regression, with market share as a dependent variable and the marginal cost as an explanatory variable, using GMM technique. The results from this estimated regression indicate that there is a negative relationship between these two variables as predicted by the new approach to measure competition. Specifically, the Boone Indicator has expected negative sign with value 0.31 , which is statistically different from zero. It implies that $100 \mathrm{bps}$ higher marginal cost of a bank is associated with 31 bps loss of market share, reflecting the underlying competitive market structure. The estimates of Boone Indictor over time show that the level of competition has intensified in the recent years. We also assessed and found these findings to be robust. Findings of this study clearly indicate that banks in Pakistan are working in competitive environment and competition increases efficiency, which is the channel through which competition is helping policy makers to make banking in Pakistan sound. Increased competition among the banks in Pakistan also means improved banking channel of monetary policy transmission mechanism, in the country.

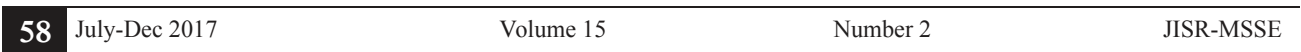




\section{REFERENCES}

Adelman, M. A. (1969), "Comment on H Concentration Measure as a Numbers Equivalent," Review of Economics and Statistics, Vol. 51, pp. 99-101.

Andries, A. M. and Capraru, B. (2012), "Competition and efficiency in EU27 Banking Systems," Baltic Journal of Economics, 12(1), pp. 41-60.

Arby, M. F. (2003), "Structure and Performance of Commercial Banks in Pakistan", MPRA Paper No. 4983.

Bhatti, G. A. and Hussain, H. (2010), "Evidence on Structure Conduct Performance Hypothesis in Pakistani Commercial Banks," International Journal of Business and Management, 5 (9), pp. 174-187.

Bikker, J., Spierdijk, L. and Finnie, P. (2006), "Misspecification of Panzar-Rosse Model: Assessing Competition in the Banking Industry," DNB Working Paper No. 114.

Boone, J. (2000), “Competition,” CEPR Discussion Paper No. 2636.

A New way to Measure Competition (2004), CEPR Discussion Paper No. 4330

A New way to Measure Competition (2008), Economic Journal, (118), pp.1245-1261.

Claessens, S. and Laeven, L. (2004), "What Derives Bank Competition? Some International Evidence," Journal of Money, Credit and Banking, 36(3), pp 563-584

Clerides, S., M. D. Delis, and S. Kokas (2015), “A New Data Set on Competition in National Banking Markets," Discussion Paper, New York University Salomon Center for Study of Financial Institutions.

Davies, S.W. (1979), "Choosing between Concentration Indices: The Iso-Concentration Curve," Econometrica, 46, pp.67-75.

Demsetz, H. (1973), "Industry Structure, Market Rivalry and Public Policy," Journal of Law and Economics, 16, pp. 1-10.

Gajurel, D. P. and Pradhan, R. S. (2012), "Concentration and Competition in Nepalese Banking," Journal of Business, Economics and Finance, 1(1), pp. 5-16.

Griffith, R., Boone, J. and Harrison, R. (2005), "Measuring Competition," AIM Research Working Paper No.22

Hall, M. and Tideman, N. (1967), "Measures of Concentration," Journal of the American Statistical Association, 62(317), pp. 162-168.

Khan, M. H.(2009), “An Analysis of Degree of Competition in Banking Sector of Pakistan through a Direct Measure of Market Contestability," SBP Research Bulletin, (2),pp. 37-52.

Khan, M. H. and Hanif, M. N. (2017a), "An Empirical Evaluation of StructureCon duct-Performance and Efficient-Structure Paradigms in Banking Sector of Pakistan," SBP Working Paper No.90

Formal Test of Competition in Banking Sector of Pakistan: An Application of PR-H Statistic (2017b)," SBP Working Paper No.91

Kwoka, J. (1985), "The Herfindahl Index in Theory and Practice," Antitrust Bulletin, 30,pp. 915-947.

Leuvensteijn, M. V., Bikker, J. A., Van Rixtel, A. R. J. M. and Sorensen, C. K. (2011), “A New Approach to Measuring Competition in the Loan Markets of the Euro Area,"Applied Economics, 43(23), pp. 3155-3167.

Leuvensteijn, M. V., Sorensen, C. K., Bikker, J.K. and Van Rixtel, A. R. J. M. (2013), “Impact of Bank Competition on the Interest Rate Pass-through in the Euro Area," Applied 
Economics, 45(11), pp. 1359-1380.

Mirza F. M., Bergland O., and Khatoon, I. (2016), "Measuring the Degree of Competition in Pakistan's Banking Industry: An Empirical Analysis," Applied Economics, 48 (53), pp 5138-5151.

Mirzaei A. and T. Moore (2014), "What are the driving forces of bank competition across different income groups of countries?" Journal of International Financial Markets, Institutions \& Money, 32, pp. 38-71.

Panzar, J.C. and Rosse, J.N. (1987), "Testing for Monopoly Equilibrium," Journal of Industrial Economics, 35, pp. 443-456.

Peltzman, S. (1977), “The Gains and Losses from Industrial Concentration," Journal of Law and Economics, 20, pp. 229-263.

Rhodes, S.A. (1995), "Market Share Inequality, the HHI, and Other Measures of the Firm-Composition of Market," The Review of Industrial Organization, 10, pp. 657-674.

Rosse, J.N. and J.C. Panzar (1977), "Chamberlin vs. Robinson: an Empirical Test for Monopoly Rent," Bell Laboratories Economic Discussion Papers, No. 90.

Schaeck, K. and Čihák, M., (2010), "Competition, Efficiency, and Soundness in Banking: An Industrial Organization Perspective" European Banking Center Discussion Paper No. 2010-20S

World Bank (2017), "Boone Indicator for Banking Market in Pakistan", retrieved (on July 31, 2017) from https://fred.stlouisfed.org/series/DDOI05PKA156NWDB 